\title{
Eimeria species in dairy and beef cattle of different ages in Goiás state, Brazil
}

\author{
Espécies de Eimeria em bovinos de leite e corte de diferentes idades no Estado de Goiás, Brasi \\ Leonardo Bueno Cruvinel ${ }^{1}$; João Eduardo Nicaretta ${ }^{1}$; Thiago de Souza Azeredo Bastos ${ }^{1}$; \\ Luiz Fellipe Monteiro Couto ${ }^{1}$; Jordana Belos dos Santos ${ }^{1}$; Dina María Beltrán Zapa ${ }^{1}$; \\ Alliny Souza de Assis Cavalcante ${ }^{1}$; Breno Cayeiro Cruz²; Dyego Gonçalves Lino Borges ${ }^{3}$; \\ Fernando de Almeida Borges ${ }^{3}$; Vando Edésio Soares ${ }^{4}$; Welber Daniel Zanetti Lopes ${ }^{1,5 *}$ \\ ${ }^{1}$ Escola de Veterinária e Zootecnia - EVZ, Universidade Federal de Goiás - UFG, Campus Samambaia, Goiânia, GO, Brasil \\ ${ }^{2}$ Faculdade de Ciências Agrárias e Veterinárias - FCAV, Universidade Estadual Paulista - UNESP, Jaboticabal, SP, Brasil \\ ${ }^{3}$ Universidade Federal do Mato Grosso do Sul - UFMS, Campo Grande, MS, Brasil \\ ${ }^{4}$ Universidade Brasil, Campus de Descalvado, São Paulo, SP, Brasil \\ ${ }^{5}$ Instituto de Patologia Tropical e Saúde Pública - IPTSP, Universidade Federal de Goiás - UFG, Goiânia, GO, Brasil
}

Received October 25, 2017

Accepted April 19, 2018

\begin{abstract}
This study aimed to identify the frequency of occurrence of Eimeria species in Holstein (taurine dairy cattle) and Nelore (zebu beef cattle) on 12 farms in the state of Goiás, Brazil. A total of 2,601 animals were evaluated, and the cattle were divided into the following age-group categories: up to three months old, four to eight months old, nine to 16 months old and cows. Fecal samples were collected directly from the rectum of all animals. None of the cattle presented any clinical signs of eimeriosis during the survey. From the results obtained, it could be concluded that higher rates of infection by Eimeria spp. were observed in Holstein cattle between the $1^{\text {st }}$ and $16^{\text {th }}$ months of age and in Nelore cattle between the $1^{\text {st }}$ and $8^{\text {th }}$ months of age. Twelve and nine Eimeria species were diagnosed in Holstein and Nelore cattle, respectively. However, Eimeria zuernii was more prevalent in animals up to three months old, while Eimeria bovis was more common in the remaining categories (cattle aged four months and over). Future studies on the epidemiology and/or seasonality of infection by Eimeria species in cattle, from birth onwards, are needed in order to better understand the dynamics of E. zuernii and E. bovis occurrences, especially in cattle under three months of age.
\end{abstract}

Keywords: Calves, eimeriosis, Eimeria bovis, Eimeria zuernii, OoPG.

\section{Resumo}

O presente trabalho teve como objetivo identificar a frequência das espécies de Eimeria spp. em bovinos holandeses (bovinos de leite) e Nelore (bovinos de corte) em 12 propriedades no Estado de Goiás. Foi avaliado um total de 2.601 animais, e em cada propriedade, os bovinos foram divididos nas seguintes categorias conforme a idade: até 3 meses, 4 a 8 meses, 9 a 16 meses e vacas. Amostras de fezes foram coletadas diretamente da ampola retal dos animais. Com base nos resultados obtidos pode-se concluir que em holandeses e Nelores, o maior número de bovinos infectados por Eimeria spp. foi observado do $1^{\circ}$ ao $16^{\circ}$ e do $1^{\circ}$ ao $8^{\circ}$ meses de idade, respectivamente. Náo houve nenhum caso de eimeriose clínica durante a pesquisa. Doze e nove espécies de Eimeria foram diagnosticadas em holandeses e Nelores, respectivamente. As duas espécies mais frequentes foram Eimeria bovis e Eimeria zuernii, entretanto, E. zuernii foi mais prevalente em animais até os 3 meses de idade, enquanto que E. bovis foi a mais frequente nas demais categorias de bovinos, a partir dos 4 meses de idade. Futuros estudos relacionados à epidemiologia e/ou de sazonalidade da infecçáo por espécies Eimeria spp., em bovinos desde o seu nascimento, são necessários, a fim de melhor entender a dinâmica de ocorrência de E. zuernii e E. bovis principalmente em bezerros com até 3 meses de idade.

Palavras-chave: Bovinos, eimeriose, Eimeria bovis, Eimeria zuernii, OoPG. 


\section{Introduction}

The cattle industry is of huge social and economic importance worldwide. Among the main hindrances to production are gastrointestinal illnesses, especially in relation to younger animals. Their impact on production usually consists of the consequences of delayed growth, and even mortality in some cases (FELIPPELLI et al., 2014).

Among the main intestinal illnesses, eimeriosis stands out. This disease is caused by protozoa belonging to the phylum Apicomplexa, class Coccidia and genus Eimeria. Twelve species that can parasitize cattle have already been described (JOYNER et al., 1966; JOLLEY \& BARDSLEY, 2006). These present complex biological cycles characterized by fast dissemination. Their infective form (sporulated oocysts) are spread on soil, vegetation or water and are able to remain viable for months in these environments (SVENSSON et al., 1994; LIMA, 2004).

Although there are 12 Eimeria species with the potential to cause losses of productivity in herds around the world, E. zuernii and $E$. bovis are considered to be the most pathogenic species, and these are responsible for clinical cases of eimeriosis in cattle (LIMA, 2004; TAUBERT et al., 2008; BRUHN et al., 2011). Both of these species, depending on animal category and degree of infection, can cause severe damage to their hosts and may even lead to mortality among cattle in the most susceptible categories (LIMA, 2004; TAUBERT et al., 2008; BRUHN et al., 2011).

Although eimeriosis is widely distributed, the frequencies of the parasite species that cause it in some regions of the world, including
Goiás Brazil, are still unknown. Eimeria species parasitizing cattle have been identified in some regions of Brazil (REBOUÇAS et al., 1994; ALMEIDA et al., 2011; BRUHN et al., 2011 whith incidence rate of $22.6 \%$ to $43.6 \%$ ), as well as in Tanzania (CHIBUNDA et al., 1997 - incidence of 35.0\%), Turkey (CICEK et al., 2007 - incidence of 20.0\%), Pakistan (REHMAN et al., 2011 - incidence of 47.9\%), Germany (BANGOURA et al., 2012 - incidence of 95.4\%), Iran (BAHRAMI \& ALBORZI, 2013 - incidence of 50.4\%), United States (LUCAS et al., 2014 - incidence of 96.0\%) and Poland (TOMCZUK et al., 2015 - incidence of 52.8\%). Moreover, in the literature consulted, there are no studies describing species identification of Eimeria spp. in cattle in the state of Goiás, central-western region of Brazil, and this factor served as the motivation for conducting the present study.

Within this context, the objective of the present investigation was to identify the frequencies of occurrence of Eimeria species and their degree of infection in naturally infected Holstein (taurine dairy cattle) and Nelore (zebu beef cattle) cattle in different age groups, in the Brazilian state of Goiás.

\section{Materials and Methods}

\section{Selection of farms and animals}

The present study was conducted between March 2015 and December 2016, on 12 farms, among which six focused on milk production and six on beef production. These farms were located in 12 different municipalities in the state of

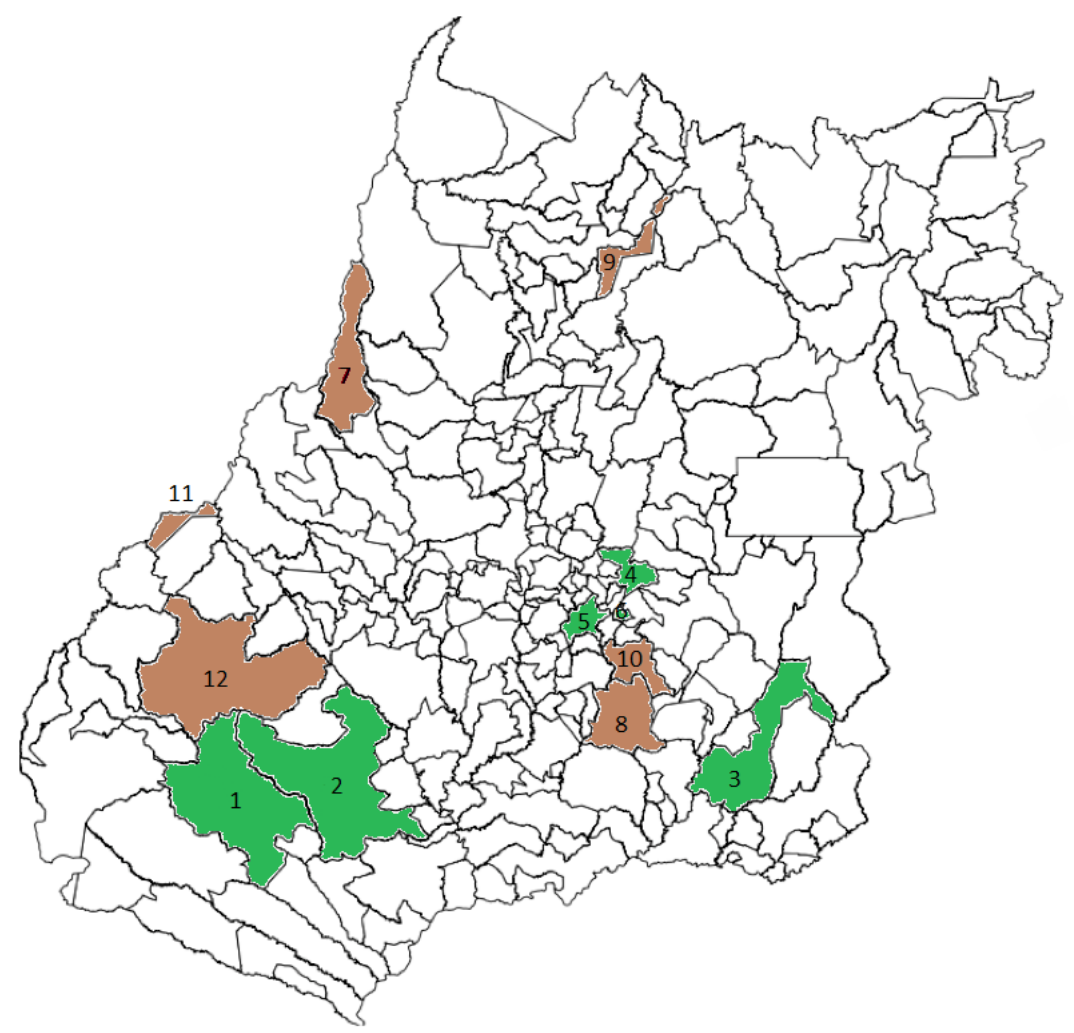

1 - Jataí

2 - Rio Verde

3 - Ipameri

4 - Anápolis

5 - Goiânia

6 - Bonfinópolis

7 - Aruanã

8 - Piracanjuba

9 - Campinorte

10 - Bela Vista de Goiás

11 - Aragarças

12 - Caiapônia

Figure 1. Spatial distribution of the municipalities in which the 12 rural properties were analyzed during the experiment, divided by aptitude (green counties cities indicate milk producing farms [Holstein cattle] and brown counties represent beef cattle herds [Nelore animals]). 
Goiás (Figure 1). The climate in this state comprises tropical savanna, which corresponds to Köppen climate classification categories "Aw" and "As". The average annual temperature is $23{ }^{\circ} \mathrm{C}$. The rainy season ocorrus from October to April andthe dry season from May to September.

With the objective of analyzing the parasite burdens of Eimeria spp. in cattle of different ages, on each farm, the animals evaluated were divided into the following age categories: up to three months old, four to eight months old, nine to 16 months old and cows. None of the farms selected presented any history of using any formulations or drugs that have any effects against eimeriosis. The herds of beef cattle were formed by Nelore animals (zebu beef cattle), which were managed through extensive breeding systems, in which the animals were provided with pasture and water ad libitum, but did not receive any supplementary feed.

In the herds that were focused on milk production, nearly 99\% of all animals were Holstein (taurine dairy cattle). On two of the farms selected, there were a few half-breed Holstein cattle but, since the number of half-breed animals was not significant, all cattle originating from these farms were considered to be of European origin, i.e. Taurine dairy cattle.

To better understand the degree of Eimeria infection in the different categories (age) and aptitude (milk or beef cattle), the results of the OoPG counts were subdivided into scales of values, according to recommendations made by Lopes et al. (2013), adapted, and will be presented in the Tables 1 an 4 of the present manuscript.

In this case, suckling calves were reared in isolation from their mothers in "houses" (Australian or Argentinian systems) or even in collective stalls. After weaning, which took place when the animals were approximately three months old, they were released into paddocks containing grass. On all the milk-producing farms, from weaning until first calving, the females were reared on pasture. On four of these farms, paddock rotation was used. Dry and/or lactating cows were reared using paddock rotation or fixed paddocks (no rotation system) or, in some cases, were kept in barn compounds. On all six dairy farms, all animals in the different categories with aptitude for milk production received daily supplementation with commercial feed.

\section{Collection of fecal samples and observation of animals}

On these 12 farms, fecal samples were collected from 2,601 cattle, comprising 1,907 of Nelore animals (zebu beef cattle) origin and 694 of Holstein (taurine dairy cattle) origin. All the samples were obtained directly from the rectum of the animals and, after individual identification (using the animal's ID number), these samples were stored in isothermal containers filled with ice. They were subsequently sent to the Veterinary Parasitology Center of the Veterinary and Animal Husbandry School, Federal University of Goiás (Centro de Parasitologia Veterinária da Escola de Veterinária e Zootecnia da Universidade Federal de Goiás, EVZ/UFG), for processing.

Additionally, at the time of the sample collection, all the cattle were evaluated for the presence of diarrhea, with or without blood, in an attempt to correlate any such symptoms to possible infection of these cattle by Eimeria spp. The aim was to determine whether eimeriosis might be occurring clinically in the herds, and to what extent this might be occurring (percentage).

\section{Processing of samples and identification of Eimeria species}

From each feces sample collected, an aliquot was taken for quantification of Eimeria spp. oocysts per gram (OoPG) of feces (GORDON \& WHITLOCK, 1939, as modified by UENO \& GONÇALVES, 1998). Each oocyst found corresponded to 50 OoOG.

For each farm, all samples from the same animal category that presented OoPG counts greater than or equal to 50 were put together in pools. In this case, five grams of faeces were used from each animal to compose the pools. For example: in the farm X if there were 100 animals belong to specific category with OoPG counts greater than or equal to 50 , five grams of each of these

Table 1. Number of infected animals and frequency of occurrence; according to range of infection of counts of oocysts per gram (OoPG) of feces, considering different categories (ages) of Holstein (taurine dairy cattle) on the state of Goiás, Center-West region of Brazil.

\begin{tabular}{|c|c|c|c|c|c|c|c|c|c|c|}
\hline \multirow{3}{*}{$\begin{array}{l}\text { OoPG counts } \\
\text { (Range of } \\
\text { infection) }\end{array}$} & \multicolumn{10}{|c|}{$\begin{array}{c}\text { Analyzed category / number of infected animals; frequency of occurrence according to } \\
\text { range of infection of Eimeria spp. oocysts }\end{array}$} \\
\hline & \multicolumn{2}{|c|}{ Up to three months } & \multicolumn{2}{|c|}{ Four to eight months } & \multicolumn{2}{|c|}{ Nine to 16 months } & \multicolumn{2}{|c|}{ Cows } & \multicolumn{2}{|c|}{ Total } \\
\hline & $\mathbf{N}^{*}$ & $\mathbf{F}(\%)^{* *}$ & $\mathbf{N}$ & $\mathrm{F}(\%)$ & $\mathbf{N}$ & F (\%) & $\mathbf{N}$ & $F(\%)$ & $\mathbf{N}$ & F (\%) \\
\hline 0 & 99 & 83.2 & 97 & 71.9 & 103 & 45.4 & 193 & 90.61 & 492 & 70.9 \\
\hline $50-100$ & 5 & 4.2 & 15 & 11.1 & 25 & 11 & 8 & 3.76 & 53 & 7.6 \\
\hline $150-200$ & 5 & 4.2 & 10 & 7.4 & 23 & 10.1 & 4 & 1.88 & 42 & 6.1 \\
\hline $250-400$ & 2 & 1.7 & 6 & 4.4 & 24 & 10.6 & 4 & 1.88 & 36 & 5.2 \\
\hline $450-600$ & 4 & 3.4 & 2 & 1.5 & 18 & 7.9 & 1 & 0.47 & 25 & 3.6 \\
\hline $650-1000$ & 2 & 1.7 & 2 & 1.5 & 16 & 7.0 & 1 & 0.47 & 21 & 3.0 \\
\hline $1050-2500$ & 0 & 0.0 & 3 & 2.2 & 16 & 7.0 & 2 & 0.94 & 21 & 3.0 \\
\hline $2550-5000$ & 1 & 0.8 & 0 & 0.0 & 2 & 0.9 & 0 & 0.00 & 3 & 0.4 \\
\hline $5050-13000$ & 1 & 0.8 & 0 & 0.0 & 0 & 0.0 & 0 & 0.00 & 1 & 0.1 \\
\hline Total & 119 & 100 & 135 & 100 & 227 & 100 & 213 & 100 & 694 & 100 \\
\hline
\end{tabular}

${ }^{*}$ Number of infected animals; ${ }^{* *}$ Frequency. 
100 animals were used to compose the pool, and in a farm Y if there were 20 animals belong to specific category with OoPG counts greater than or equal to 50 , five grams of each of these 20 animals were used to compose the pool. These pools were then processed using the method of centrifugal flotation in sugar solution. After this, these samples were filtered using sieves with folded gauze. A $2 \%$ potassium dichromate $\left(\mathrm{K}_{2} \mathrm{Cr}_{2} \mathrm{O}_{7}\right)$ solution was added to the results from this filtration, volume by volume, and this mixture was kept at $24^{\circ} \mathrm{C}$ for 14 days, under oxygenation (using aquarium oxygenator pumps), in order to stimulate oocyst sporulation under laboratory conditions.

Oocysts were recovered by means of centrifugation in a $60 \%$ saturated sugar solution, and approximately 100 oocysts per pool (of each animal category) from each farm were identified under an optical microscope coupled to a computerized system (LAS, Leica). This process of recovering 100 oocysts per pool for identification of Eimeria species was performed in triplicate. Differentiation between species was done according to the phenotypic characteristics of the oocysts, such as color, presence or absence of micropyle and length and width (DAUGSCHIES \& NAJDROWSKI, 2005).

\section{Data analysis}

Even after transformation of ocysts per gram of faeces counts into neperian logarithm $[\ln ($ counts of $\mathrm{OoPg}+1)]$, the data did not present prerogatives of normality, homogeneity of variance and randomness of the errors. Because of this, the Kruskal-Wallis non-parametric test was used, by the Simes-Hochberg multiple comparison method, and the data were analyzed in a completely randomized design comparing the different categories (ages) within each aptitude (milk and beef cattle), at the level of 5\% of significance, using the SAS software, version 9.0 (SAS, 2002).

A comparative analysis between races can not be performed because it was not the objective of the study, since such races has different production objectives and management methods. In addition, a different design should have been carried out for this study

\section{Results}

Among all the 2,601 feces samples analyzed, 667 (25.6\%) presented OoPG counts greater than or equal to 50 Eimeria spp. oocysts. Furthermore, independent of category and aptitude (Holstein or Nelore), none of the cattle presented any clinical signs of eimeriosis during the survey, even though a few animals presented high parasite burdens. Therefore, the form of the illness that was observed was classified as subclinical eimeriosis.

\section{Holstein (taurine dairy cattle)}

Regarding Holstein taurine dairy cattle, 694 fecal samples were analyzed, out of which 202 (29.1\%) presented OoPG counts greater than or equal to 50 . Out of these 202 animals infected with Eimeria, 98.01\% presented OoPG counts between 50 and 2,500 (Table 1). The animal diagnosed with the highest Eimeria OoPG count was a calf aged under three months, which presented 13,000 oocysts per gram of feces. Table 1 shows that the largest number of cattle diagnosed with Eimeria spp. (124 cattle; $54.6 \%$ ) were in the age range from nine to 16 months, followed by animals between four and eight months old $(38 ; 28.1 \%)$, up to three months old $(20 ; 20 \%)$ and cows $(20 ; 9.4 \%)$.

The results obtained through the statistical analysis showed that the average OoPG counts from the animals between nine and 16 months old were higher than the others categories (Table 2).

Table 3 shows that on all six farms that focused on milk production, it was possible to identify 12 Eimeria species, in decreasing order of frequency of occurrence: E. bovis $(39.9 \%)$, E. zuernii (24.6\%), E. canadensis (10.3\%), E. ellipsoidalis (9.0\%), E. wyomingensis (5.5\%), E. cylindrica (5.0\%), E. auburnensis $(2.2 \%)$, E. brasiliensis (2.2\%), E. subspherica (1.0\%), E. alabamensis (0.5\%), E. pellita (0.2\%) and E. bukidnonensis (0.03\%). In evaluating the prevalences of Eimeria species in different categories, it was seen that E. zuernii was the most frequent species in cattle up to three months of age $(47.1 \%)$, while E. bovis prevailed in the remaining categories (four to eight months, nine to 16 months and cows), with respective frequencies of $26.0 \%, 55.1 \%$ and $70.5 \%$ (Table 3 ).

\section{Nelore (zebu beef cattle)}

Concerning Nelore zebu beef animals, 24.4\% (465) of all the fecal samples evaluated contained Eimeria spp. oocysts. In analyzing only these 465 infected cattle, it could be seen that $50.96 \%$ of them presented OoPG counts between 50 and 200, and that 98.26\% presented OoPG counts between 50 and 2,500 (Table 4). The highest OoPG value obtained among Nelore cattle $(8,950)$ was from an animal in the group aged between four and eight months. In this category, the observed frequency of Eimeria spp. parasitism was $30.23 \%$ (432 animals), followed by animals of ages up to three months $(24 ; 35.29 \%)$, cows $(7 ; 4.76 \%)$ and animals between nine and 16 months (2;0.7\% (Table 4).

Table 2. Analysis regarding average counts of Eimeria spp. oocysts per gram (OoPG) of feces, in different categories of Nelore (zebu beef cattle) and Holstein (taurine dairy cattle) on the state of Goiás, Center-West region of Brazil.

\begin{tabular}{|c|c|c|c|c|c|c|c|c|c|c|c|c|}
\hline \multirow{3}{*}{$\begin{array}{l}\text { Origin/ } \\
\text { Aptitude }\end{array}$} & \multicolumn{12}{|c|}{ Analyzed category /Average counts ${ }^{1}$ of oocysts per gram (OoPG -Eimeria spp.) of feces } \\
\hline & \multicolumn{3}{|c|}{ Up to three months } & \multicolumn{3}{|c|}{ Four to eight months } & \multicolumn{3}{|c|}{ Nine to 16 months } & \multicolumn{3}{|c|}{ Cows } \\
\hline & Average & ounts & Range & Averag & unts & Range & Averag & unts & Range & Avera & unts & Range \\
\hline Milk (Holstein) & 194.9 & $\mathrm{AB}$ & $(0-13,000)$ & 89.7 & $\mathrm{~B}$ & $(0-1,850)$ & 310.7 & A & $(0-4,950)$ & 32.8 & $\mathrm{C}$ & $(0-1,700)$ \\
\hline Beef (Nelore) & 161.0 & $\mathrm{~B}$ & $(0-1,950)$ & 525.2 & A & $(0-8,950)$ & 0.95 & $\mathrm{C}$ & $(0-150)$ & 3.4 & $\mathrm{C}$ & $(0-150)$ \\
\hline
\end{tabular}

${ }^{1}$ Averages followed by the same letters, capital letters in each line, do not differ amongst themselves $(\mathrm{P}>0.05)$. 
Table 3. Eimeria species identified in different Holstein (taurine dairy cattle) categories, naturally infected, on the state of Goiás, Center-West region of Brazil.

\begin{tabular}{|c|c|c|c|c|c|}
\hline \multirow{3}{*}{ Eimeria species } & \multicolumn{5}{|c|}{ Analyzed category/Frequency (\%) of identified Eimeria species } \\
\hline & $\begin{array}{l}\text { Up to three months } \\
\text { (119 animals) }\end{array}$ & $\begin{array}{l}\text { Four to eight months } \\
\text { (135 animals) }\end{array}$ & $\begin{array}{l}\text { Nine to } 16 \text { months } \\
\text { (227 animals) }\end{array}$ & $\begin{array}{c}\text { Cows } \\
\text { (213 animals) }\end{array}$ & Total \\
\hline & $\mathrm{F}^{*}(\%)$ & $\overline{F(\%)}$ & $\mathbf{F}(\%)$ & $\mathbf{F}(\%)$ & F (\%) \\
\hline E. alabamensis & 0.00 & 2.00 & 0.12 & 0.00 & 0.53 \\
\hline E. auburnensis & 7.02 & 0.00 & 1.60 & 0.00 & 2.16 \\
\hline E. bovis & 7.80 & 26.00 & 55.10 & 70.50 & 39.85 \\
\hline E. brasiliensis & 3.02 & 0.65 & 5.21 & 0.00 & 2.22 \\
\hline E. bukidnonensis & 0.00 & 0.00 & 0.12 & 0.00 & 0.03 \\
\hline E. canadensis & 14.52 & 16.70 & 9.81 & 0.00 & 10.26 \\
\hline E. cylindrica & 3.15 & 15.66 & 1.13 & 0.00 & 4.87 \\
\hline E. ellipsoidalis & 8.85 & 13.51 & 1.70 & 11.80 & 8.87 \\
\hline E. pellita & 0.00 & 0.65 & 0.00 & 0.00 & 0.16 \\
\hline E. subspherica & 1.59 & 0.53 & 0.88 & 0.00 & 0.98 \\
\hline E. wyomingensis & 7.01 & 1.10 & 8.08 & 5.90 & 5.51 \\
\hline E. zuernii & 47.04 & 23.20 & 16.25 & 11.80 & 24.56 \\
\hline
\end{tabular}

*Frequency.

Table 4. Number of infected animals and frequency of occurrence; according to range of infection of counts of oocysts per gram (OoPG) of feces, considering different categories (ages) of Nelore (zebu beef cattle) on the state of Goiás, Center-West region of Brazil.

\begin{tabular}{|c|c|c|c|c|c|c|c|c|c|c|}
\hline \multirow{3}{*}{$\begin{array}{l}\text { OoPG counts } \\
\text { (Range of } \\
\text { infection) }\end{array}$} & \multicolumn{10}{|c|}{$\begin{array}{l}\text { Analyzed category/number of infected animals; frequency of occurrence according to range of infection of Eimeria } \\
\text { spp. oocysts }\end{array}$} \\
\hline & \multicolumn{2}{|c|}{ Up to three months } & \multicolumn{2}{|c|}{ Four to eight months } & \multicolumn{2}{|c|}{ Nine to 16 months } & \multicolumn{2}{|c|}{ Cows } & \multicolumn{2}{|c|}{ Total } \\
\hline & $\mathrm{N}^{*}$ & $\mathbf{F}(\%)^{* *}$ & $\mathbf{N}$ & F (\%) & $\mathbf{N}$ & F (\%) & $\mathbf{N}$ & F (\%) & $\mathbf{N}$ & F (\%) \\
\hline 0 & 44 & 64.7 & 997 & 69.8 & 261 & 99.2 & 140 & 95.24 & 1442 & 75.6 \\
\hline $50-100$ & 11 & 16.2 & 154 & 10.8 & 1 & 0.4 & 6 & 4.08 & 172 & 9.0 \\
\hline $150-200$ & 2 & 2.9 & 61 & 4.3 & 1 & 0.4 & 1 & 0.68 & 65 & 3.4 \\
\hline $250-400$ & 3 & 4.4 & 88 & 6.2 & 0 & 0.0 & 0 & 0.00 & 91 & 4.8 \\
\hline $450-600$ & 3 & 4.4 & 31 & 2.2 & 0 & 0.0 & 0 & 0.00 & 34 & 1.8 \\
\hline $650-1000$ & 1 & 1.5 & 44 & 3.1 & 0 & 0.0 & 0 & 0.00 & 45 & 2.4 \\
\hline $1050-2500$ & 4 & 5.9 & 32 & 2.2 & 0 & 0.0 & 0 & 0.00 & 36 & 1.9 \\
\hline $2550-5000$ & 0 & 0.0 & 12 & 0.8 & 0 & 0.0 & 0 & 0.00 & 12 & 0.6 \\
\hline $5050-13000$ & 0 & 0.0 & 10 & 0.7 & 0 & 0.0 & 0 & 0.00 & 10 & 0.5 \\
\hline Total & 68 & 100 & 1429 & 100 & 263 & 100 & 147 & 100 & 1907 & 100 \\
\hline
\end{tabular}

${ }^{*}$ Number of infected animals; ${ }^{* *}$ Frequency.

In analyzing these results statistically, it could be seen that the average OoPG count among animals up to eight months of age was higher $(\mathrm{P} \leq 0.05)$ than the average count among animals between nine and 16 months of age and the count among cows (Table 2).

On the farms that focused on rearing beef cattle, it was possible to identify nine species of Eimeria (Table 5), in decreasing order of frequency of occurrence: E. bovis (28.2\%), E. zuernii (24.0\%), E. brasiliensis (22.4\%), E. canadensis (9.8\%), E. wyomingensis $(5.9 \%)$, E. auburnensis (2.9\%), E. ellipsoidalis (2.7\%), E. cylindrica (2.5\%) and E. alabamensis (1.6\%). As was observed for Holstein, E. zuernii was the most frequent species diagnosed in Nelore up to three months of age (68.4\%), while E. bovis prevailed in animals from four to eight months old, nine to 16 months old and cows, with frequencies of $22.3 \%, 59.8 \%$ and $30.2 \%$, respectively (Table 5).

\section{Discussion}

To the best of the present authors' knowledge, this was the first study to identify Eimeria species in Holstein (taurine dairy cattle) and Nelore (zebu beef cattle) herds in the state of Goiás, in the central-western region of Brazil. This state accounts for a significant proportion of these animal species, in relation to the remainder of the country.

During the present study, 12 species were identified, encompassing all the farms analyzed in different regions of this state. The total number of Eimeria species identified in this survey differed from results obtained by other researchers throughout Brazil (REBOUÇAS et al., 1994; ALMEIDA et al., 2011; BRUHN et al., 2011; RODRIGUES, 2014), and also from the results reported from other regions of the world, such 
Table 5. Eimeria species identified in different Nelore (zebu beef cattle) categories, naturally infected, on the state of Goiás, Center-West region of Brazil.

\begin{tabular}{|c|c|c|c|c|c|}
\hline \multirow{3}{*}{ Eimeria species } & \multicolumn{5}{|c|}{ Analyzed category / Frequency (\%) of identified Eimeria species } \\
\hline & $\begin{array}{l}\text { Up to three months } \\
\text { (68 animals })\end{array}$ & $\begin{array}{c}\text { Four to eight months } \\
(1,429 \text { animals })\end{array}$ & $\begin{array}{l}\text { Nine to } 16 \text { months } \\
\text { (263 animals) }\end{array}$ & $\begin{array}{c}\text { Cows } \\
\text { (147 animals) }\end{array}$ & Total \\
\hline & $\mathrm{F}^{*}(\%)$ & $\begin{array}{c}\mathbf{F}(\%) \\
\end{array}$ & $\mathbf{F}(\%)$ & $\mathbf{F}(\%)$ & $\mathbf{F}(\%)$ \\
\hline E. alabamensis & 6.20 & 0.00 & 0.00 & 0.00 & 1.55 \\
\hline E. auburnensis & 9.80 & 1.94 & 0.02 & 0.00 & 2.92 \\
\hline E. bovis & 0.50 & 22.33 & 59.80 & 30.20 & 28.21 \\
\hline E. brasiliensis & 0.20 & 44.66 & 0.10 & 44.70 & 22.42 \\
\hline E. canadensis & 0.00 & 8.74 & 5.28 & 25.10 & 9.78 \\
\hline E. cylindrica & 0.20 & 0.97 & 8.70 & 0.00 & 2.47 \\
\hline E. ellipsoidalis & 8.90 & 1.94 & 0.00 & 0.00 & 2.71 \\
\hline E. wyomingensis & 5.80 & 10.68 & 7.30 & 0.00 & 5.95 \\
\hline E. zuernii & 68.40 & 8.74 & 18.80 & 0.00 & 23.99 \\
\hline
\end{tabular}

${ }^{*}$ Frequency.

as Saudi Arabia, Pakistan and Tanzania (KASIM \& AL-SHAWA, 1985; CHIBUNDA et al., 1997; REHMAN et al., 2011), where between six and 11 species were observed. This difference in the total number of species and also in the diversity of Eimeria spp. identified in different regions occurred even though E. subspherica, E. pellita and E. bukidnonensis were not diagnosed in the Nelore cattle examined in the present study.

In studies conducted in Brazil (REBOUÇAS et al., 1994; ALMEIDA et al., 2011; BRUHN et al., 2011; RODRIGUES, 2014) and other regions of the world (CHIBUNDA et al., 1997; CICEK et al., 2007; REHMAN et al., 2011; BANGOURA et al., 2012; BAHRAMI \& ALBORZI, 2013; LUCAS et al., 2014), Eimeria bovis was the most frequent species. These results led these researchers to describe $E$. bovis as the most frequent species worldwide. In the present study, considering all categories, E. bovis $(34.0 \%)$ was the most prevalent species in both Holstein and Nelore, followed by E. zuernii (24.3\%). However, in analyzing different categories separately, it could be seen that in cattle up to three months of age (Holstein and Nelore), E. zuernii was the most frequent species ( $47.1 \%$ and $68.4 \%$, respectively), while $E$. bovis infections prevailed in animals aged four months and over. The only study that presented results similar to these, concerning the prevalences of E. zuernii and E. bovis according to age, was one conducted in Poland by Tomczuk et al. (2015). One possible explanation for the differences observed in the present study, regarding the prevalence of E. zuernii in animals up to three months of age, in comparison with the previous studies mentioned above, is that it may have been because the authors of those studies did not divide the ages of the animals to the extent done here, in analyzing their samples. This means that, in those studies, cattle classified as young encompassed a wide range of ages, from birth up to 12 or 18 months of age. Also, in some of those previous studies, feces were only collected from animals aged over seven or eight months, which could also explain the observed difference.

From the results found in the present study, and also the results described by Tomczuk et al. (2015) in Poland, it is clear that E. zuernii could be the most prevalent species in cattle under three or four months of age, while E. bovis is the most frequent species in animals older than four or five months. Thus, an inversion in frequency between E. zuernii and E. bovis seems to occur as the animals grow older. In other words, there is a decrease in the parasite burdens due to E. zuernii in cattle, and a concomitant increase in the frequency of $E$. bovis as the animals grow older. Nonetheless, further studies on the epidemiology and/or seasonality of infections by Eimeria spp. in cattle, from their birth up until they reach 12 or 24 months, are needed in different regions, with the aim of reinforcing or disproving the findings of the present survey, as well as those obtained in Poland by Tomczuk et al. (2015).

Although some of the animals in the present study showed high OoPG counts $(\geq 10,000)$, the infection presented by all of the cattle examined was classified as subclinical, since no clinical sign that would suggest presence of eimeriosis in these animals was observed in any of the feces collections. In other studies, it has been reported that the asymptomatic form is more commonly observed in adults, while young animals between three and six months of age are the most susceptible to the clinical forms of this disease (KOUTNY et al., 2012; RODRIGUES, 2014). In other projects conducted around the world (REBOUÇAS et al., 1994; CHIBUNDA et al., 1997; ALMEIDA et al., 2011; BRUHN et al., 2011; REHMAN et al., 2011; RODRIGUES 2014), which encompassed animals in different age categories, these animals also presented subclinical eimeriosis.

The prevalence of infection by Eimeria spp. among the animals of the present study was $29.1 \%$ for Holstein and $24.4 \%$ for Nelore . Comparatively, these results were similar to, or even a little lower than the results obtained by other researchers $(35.0 \%$, KASIM \& AL-SHAWA, 1985; 43.6\%, REBOUÇAS et al., 1994 35.0\%, CHIBUNDA et al., 1997; 33.3\%, ALMEIDA et al., 2011; 47.9\%, REHMAN et al., 2011; 44.0\%, RODRIGUES, 2014). Andrade et al. (2012) reported that, in ruminants, adequate protein-based dietary supplementation may lead to improvement of the animal's immune system, which may reduce the burden of Eimeria spp. in cattle. This could possible explain lower OoPG counts and lower environmental contamination by this protozoon. However, despite these reports, it is essential to emphasize that, in the present study, only Holstein animals received protein-based 
supplementation. The Nelore cattle only fed on the grasses that were present on each farm.

The results regarding OoPG counts and the ages of the animals varied according to the origin of the cattle in the present study. For Holstein, the highest number of infected animals was observed in those up to 16 months of age, while for Nelore, the animals were more infected by Eimeria spp. up to the eighth month of age. In studies conducted in several other regions of the world (KASIM \& AL-SHAWA, 1985; CHIBUNDA et al., 1997; ALMEIDA et al., 2011; RODRIGUES, 2014), it was observed that the level of parasitism was higher in younger animals than in adults. Infection in this animal category can occur through failure to develop adequate immunity that would be able to protect the animal, or it may even be due to some stressful situation that makes the animals susceptible to infections (LUCAS et al., 2007; MITCHELL et al., 2012; SANCHEZ et al., 2008). Nonetheless, in the present study, the fact that the parasitism by Eimeria spp. diminished significantly in Holstein and Nelore cattle at 16 and eight months of age, respectively, may have been a reflection of the contrast between the two production systems, especially concerning the early separation of calf and cow and higher number of animal units (AU) per area, which are both characteristics of dairy farms. It is essential to emphasize that in the present study, on four out of the six farms that focused on milk production, the animals were reared in a pasture rotation system between the ages of four months and their first parturition ( \pm 24 months). Since this system allows greater numbers of animals in each pasture area, pasture rotation may possibly result in an overall increase in parasitism in these animals. In this survey, the farms that used this husbandry system had between nine and $14 \mathrm{AU}$ (one animal unit represents 450 kilograms) per hectare, which could explain the high Eimeria spp. parasitism observed in the Holstein cattle between nine and 16 months of age. However, further studies need to be conducted in order to elucidate all of the above hypotheses.

\section{Conclusion}

From the results obtained, it can be concluded that, in Holstein (taurine dairy cattle) and Nelore (zebu beef cattle), the highest numbers of animals infected by Eimeria spp. were observed between the $1^{\text {st }}$ and $16^{\text {th }}$ months and between the $1^{\text {st }}$ and $8^{\text {th }}$ months of age, respectively. No cases of clinical eimeriosis were diagnosed during this survey. Twelve and nine Eimeria species were diagnosed in Holstein (taurine dairy cattle) and Nelore (zebu beef cattle), respectively, and the two most frequent species were $E$. bovis and E. zuernii. E. brasiliensis was the most frequent in zebu cattle between the $4^{\text {st }}$ and $8^{\text {th }}$ months of age. However, E. zuernii was the most prevalent species in animals up to three months of age, while $E$. bovis was the most frequent species in the remaining age categories, i.e. four months and over. Further studies on the epidemiology and/or seasonality of infection by Eimeria species in cattle, from their birth onwards, are needed in order to elucidate the dynamics of E. zuernii and E. bovis occurrences, especially in animals up to three months of age.

\section{References}

Almeida VA, Magalhães VCS, Muniz ES Na, Munhoz AD. Frequency of species of the Genus Eimeria in naturally infected cattle in Southern Bahia, Northeast Brazil. Rev Bras Parasitol Vet 2011; 20(1): 78-81. http:// dx.doi.org/10.1590/S1984-29612011000100017. PMid:21439239.

Andrade ALF Jr, Silva PC, Aguiar EM, Santos FGA. Use of coccidiostat in mineral salt and study on ovine eimeriosis. Rev Bras Parasitol Vet 2012; 21(1): 16-21. http://dx.doi.org/10.1590/S1984-29612012000100004. PMid:22534939.

Bahrami S, Alborzi AR. Prevalence of subclinical coccidiosis in river buffalo calves of southwest of Iran. Acta Parasitol 2013; 58(4): 527-530. http://dx.doi.org/10.2478/s11686-013-0167-1. PMid:24338314.

Bangoura B, Mundt HC, Schmäschke R, Westphal B, Daugschies A. Prevalence of Eimeria bovis and Eimeria zuernii in German cattle herds and factors influencing oocyst excretion. Parasitol Res 2012; 110(2): 875-81. PMid:21808979.

Bruhn FRP, Lopes MA, Demeu FA, Perazza CA, Pedrosa MF, Guimarães AM. Frequency of species of Eimeria in females of the holstein-friesian breed at the post-weaning stage during autumn and winter. Rev Bras Parasitol Vet 2011; 20(4): 303-307. http://dx.doi.org/10.1590/S198429612011000400008. PMid:22166384

Chibunda RT, Muhairwa AP, Kambarage DM, Mtambo MMA, Kusiluka LJM, Kazwala RR. Eimeriosis in dairy cattle farms in Morogoro municipality of Tanzania. Prev Vet Med 1997; 31(3-4): 191-197. http:// dx.doi.org/10.1016/S0167-5877(96)01131-2. PMid:9234443.

Cicek H, Sevimli F, Kozan E, Köse M, Eser M, Dogan N. Prevalence of coccidia in beef cattle in western Turkey. Parasitol Res 2007; 101(5): 12391243. http://dx.doi.org/10.1007/s00436-007-0627-3. PMid:17653768.

Daugschies A, Najdrowski M. Eimeriosis in cattle: current understanding. J Vet Med B Infect Dis Vet Public Health 2005; 52(10): 417-427. http:// dx.doi.org/10.1111/j.1439-0450.2005.00894.x. PMid:16364016.

Felippelli G, Lopes WDZ, Cruz BC, Teixeira WFP, Maciel WG, Fávero FC, et al. Nematode resistance to ivermectin $(630$ and $700 \mu \mathrm{g} / \mathrm{kg})$ in cattle from the Southeast and South of Brazil. Parasitol Int 2014; 63(6): 835840. http://dx.doi.org/10.1016/j.parint.2014.08.001. PMid:25130588.

Gordon HML, Whitlock HV. A new technique for counting nematode eggs in sheep feces. J Counc Sci Ind Res 1939; 12(1): 50-52.

Jolley WR, Bardsley KD. Ruminant coccidiosis. Vet Clin North Am Food Anim Pract 2006; 22(3): 613-621. http://dx.doi.org/10.1016/j. cvfa.2006.07.004. PMid:17071356.

Joyner LP, Norton CC, Davies SF, Watkins CV. The species of coccidian occurring in cattle and sheep in the south-west of England. Parasitology 1966; 56(3): 531-541. http://dx.doi.org/10.1017/S0031182000069018. PMid:6007931.

Kasim AA, Al-Shawa YR. Prevalence of Eimeria in faeces of cattle in Saudi Arabia. Vet Parasitol 1985; 17(2): 95-99. http://dx.doi.org/10.1016/03044017(85)90094-9. PMid:3992872.

Koutny H, Joachim A, Tichy A, Baumgartner W. Bovine Eimeria species in Austria. Parasitol Res 2012; 110(5): 1893-1901. http://dx.doi. org/10.1007/s00436-011-2715-7. PMid:22167365.

Lima JD. Coccidiose dos ruminantes domésticos. Rev Bras Parasitol Vet 2004; 13(S1): 9-3.

Lopes WDZ, Borges FA, Faiolla TP, Antunes LT, Borges DGL, Rodriguez FS, et al. Eimeria species in young and adult sheep raised under intensive 
and/or semi-intensive systems of a herd from Umuarama city, Parana State, Brazil. Cienc Rural 2013; 43(11): 2031-2036. http://dx.doi.org/10.1590/ S0103-84782013001100018.

Lucas AS, Swecker WS Jr, Lindsay DS, Scaglia G, Elvinger FC, Zajac AM. The effect of weaning method on coccidial infections in beef calves. Vet Parasitol 2007; 145(3-4): 228-233. http://dx.doi.org/10.1016/j. vetpar.2007.01.002. PMid:17289269.

Lucas AS, Swecker WS Jr, Lindsay DS, Scaglia G, Neel JPS, Elvinger FC, et al. A study of the level and dynamics of Eimeria populations in naturally infected, grazing beef cattle at various stages of production in the Mid-Atlantic USA. Vet Parasitol 2014; 202(3-4): 201-206. http:// dx.doi.org/10.1016/j.vetpar.2014.02.053. PMid:24680603.

Mitchell ESE, Smith RP, Ellis-Iversen J. Husbandry risk factors associated with subclinical coccidiosis in young cattle. Vet J2012; 193(1): 119-123. http://dx.doi.org/10.1016/j.tvjl.2011.09.017. PMid:22082508.

Rebouças MM, Grasso MPS, Spósito E Fa, Amaral V, Santos SM, Silva DM. Prevalência e distribuição de protozoários do gênero Eimeria (Apicomplexa: Eimeriidae) em bovinos nos municípios de Altinópolis, Taquaritinga, São Carlos e Guairá - Estado de São Paulo, Brasil. Rev Bras Parasitol Vet 1994; 3(2): 125-130.

Rehman TU, Khan MN, Sajid MS, Abbas RZ, Arshad M, Iqbal Z, et al. Epidemiology Eimeria and associated risk factors in cattle of district Toba Tek Singh, Pakistan. Parasitol Res 2011; 108(5): 1171-1177. http://dx.doi. org/10.1007/s00436-010-2159-5. PMid:21110042.
Rodrigues FS. Eimeria spp. em ruminantes domésticos no Estado de Mato Grosso do Sul [Dissertação]. Campo Grande: Universidade Federal do Mato Grosso do Sul; 2014.

Sánchez RO, Romero JR, Founroge RD. Dynamics of Eimeria oocyst excretion in dairy calves in the Province of Buenos Aires (Argentina), during their first 2 months of age. Vet Parasitol 2008; 151(2-4): 133 138. http://dx.doi.org/10.1016/j.vetpar.2007.11.003. PMid:18096320.

Statical Analysys System - SAS. Statistical Analysis Software -Version 9.0. Cary: SAS Institute; 2002. CD-ROM.

Svensson C, Uggla A, Pehrson B. Eimeria alabamensis infection as a cause of diarrhoea in calves at pasture. Vet Parasitol 1994; 53(1-2): 33 43. http://dx.doi.org/10.1016/0304-4017(94)90014-0. PMid:8091616.

Taubert A, Hermosilla C, Suhwold A, Zahner H. Antigen-induced cytokine production in lymphocytes of Eimeria bovis primary and challenge infected calves. Vet Immunol Immunopathol 2008; 126(3-4): 309-320. http://dx.doi.org/10.1016/j.vetimm.2008.09.003. PMid:18947883.

Tomczuk K, Grzybek M, Szczepaniak K, Studzinska M, DemkowskaKutrzepa M, Roczen-Karczmarz M, et al. Analysis of intrinsic and extrinsic factors influencing the dynamics of bovine Eimeria spp. from central-eastern Poland. Vet Parasitol 2015; 214(1-2): 22-28. http://dx.doi. org/10.1016/j.vetpar.2015.09.027. PMid:26455571.

Ueno H, Gonçalves PC. Manual para diagnóstico das helmintoses de ruminantes. 4 ed. Chiyoda: Japan International Cooperation Agency; 1998. 